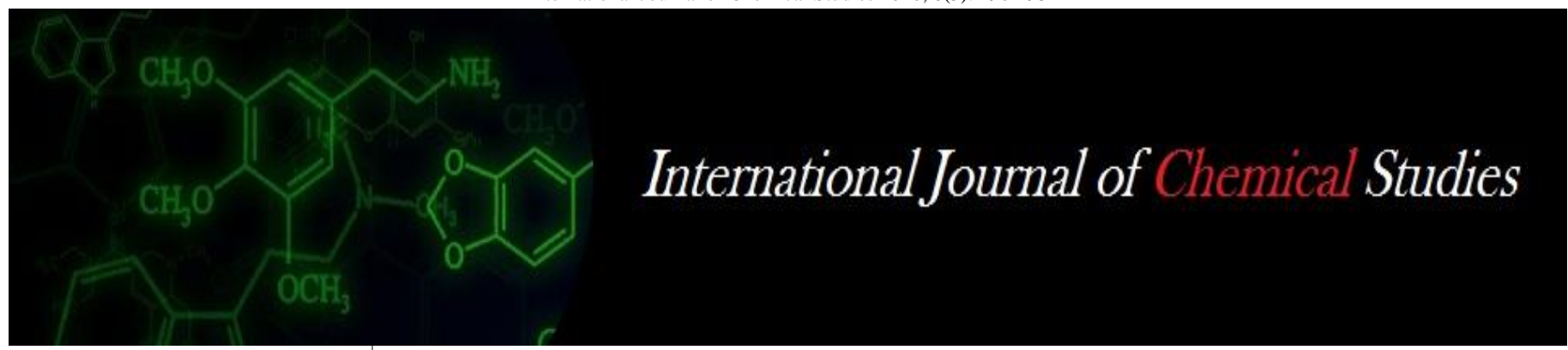

P-ISSN: 2349-8528

E-ISSN: 2321-4902

www.chemijournal.com

IJCS 2020; 8(5): 490-493

(C) 2020 IJCS

Received: 22-07-2020

Accepted: 24-08-2020

\section{GD Vandodariya}

Department of Genetics and

Plant Breeding, N M College of

Agriculture, Navsari

Agricultural University, Navsari,

Gujrat, India

\section{DA Chauhan}

Department of Genetics and

Plant Breeding, N M College of

Agriculture, Navsari

Agricultural University, Navsari,

Gujrat, India

\section{RK Patel}

Department of Genetics and

Plant Breeding, N M College of

Agriculture, Navsari

Agricultural University, Navsari,

Gujrat, India

\section{KG Modha}

Department of Genetics and

Plant Breeding, N M College of

Agriculture, Navsari

Agricultural University, Navsari,

Gujrat, India

\section{YV Naghera}

Department of Genetics and

Plant Breeding, N M College of

Agriculture, Navsari

Agricultural University, Navsari,

Gujrat, India

\section{SK Jadav}

Department of Genetics and Plant Breeding, N M College of Agriculture, Navsari

Agricultural University, Navsari, Gujrat, India
Corresponding Author: GD Vandodariya Department of Genetics and Plant Breeding, N M College of Agriculture, Navsari

Agricultural University, Navsari, Gujrat, India

\section{Genetic architecture in blackgram [Vigna mungo (L). Hepper]}

\author{
GD Vandodariya, DA Chauhan, RK Patel, KG Modha, YV Naghera and \\ SK Jadav
}

DOI: https://doi.org/10.22271/chemi.2020.v8.i5g.10346

\begin{abstract}
Generation mean analysis study was carried out to estimate the gene action governing inheritance of yield and its components in blackgram using six parameter model. Six generations of a cross NUK-15-02 $\times$ NUK-15-09 was studied. Simple scaling test as well as joint scaling test were carried out to check the adequacy of additive-dominance model. Additive gene effect had lower magnitude than dominance gene effect in most of the characters. Additive $x$ additive type of epistatis was found significance for days to first flower, plant height and branches per plant. Dominance $\times$ dominance gene interaction was registered significant by days to first flower, days to maturity and plant height. Hereby for the improvement of various characters studied in this cross, followed population improvement approach which takes in to account both additive and non-additive gene action.
\end{abstract}

Keywords: Generation mean analysis, scaling test, six parameter model, epistatis

\section{Introduction}

Blackgram or urd (Vigna mungo (L.) Hepper) is one of the most highly prized pulses in tropical countries especially in India. The green pods are eaten as vegetable and they are highly nutritious. It has inevitably marked itself as the most popular pulse and can be most appropriately referred to as the "king of the pulses" due to its mouthwatering taste and numerous other nutritional qualities. Whether it be the very special "Dal makhni" of Punjab or the "Vada Sambhar" of South India, the taste rules the hearts of one and all alike. Indian immigrants have popularized the taste worldwide as well. An erect, sub-erect or trailing, densely hairy, annual herb. The tap root produces a branched root system with smooth, rounded nodules. The pods are narrow, cylindrical and up to six $\mathrm{cm}$ long. Urd is pulse crop of many Asian countries and it belongs to tribe phaseolus family fabaceae with chromosome number $2 \mathrm{n}=22$. Blackgram an indigenous African annual legume, having high protein (20$25 \%$ ). Blackgram can be grown in all types of soil but sandy and sandy loam soils are best suited for it. Black gram's heat-loving nature makes them an ideal mid-summer replenisher of soil organic matter and mineralizable nitrogen. For consumption purpose, it is largely used to make dal from the whole or split, dehusked seeds. The bean is boiled and eaten whole or, after splitting, made into dal; prepared like this it has an unusual mucilaginous texture. In India it is mainly grown in Dadra and Nagar Haveli, Andhara Pradesh, Jarkhand, Bihar, Arunachal Pradesh, Madya Pradesh, Assam, Himachal Prdesh, Rajasthan, Gujarat, Maharashtra, and some regions of Southern India. In India, it occupies about 5279.09 thousand hectares and annual production of urd bean is about 3492.42 thousand tones with $662 \mathrm{~kg} / \mathrm{ha}$ productivity, while in Gujarat, it occupies about 136.00 thousand ha area with the production of 86.52 thousand tones, with $636 \mathrm{~kg} /$ ha productivity in year 2018. (Anon., 2018).

In India, the availability of many improved varieties has boosted production. This indicates that there is still scope to increase yield potential of varieties through genetical improvement. Various biometrical methods have been used by the plant breeder for the selection of suitable parents in their breeding material, of these, generation means analysis provides information on the nature and magnitude of gene action involved in yield and its component characters. 


\section{Materials and Methods}

The research experiment was conducted during summer-2020 at Pulses and Castor Research Station, Navsari Agricultural University, Navsari. In this experiment six generations viz., $\mathrm{P} 1, \mathrm{P} 2, \mathrm{~F} 1, \mathrm{~F} 2, \mathrm{BC} 1$ and $\mathrm{BC} 2$ of cross involving two diverse genotypes of blackgram were produced and evaluated in Compact Family Block Design with three replications. The crossing program was initiated during Summer-2019 to produce three F1 hybrids among four selected genotypes (Table 3.1); while backcrossing and selfing of F1 was done in Kharif-2019 to obtain $\mathrm{BC} 1, \mathrm{BC} 2$ and $\mathrm{F} 2$ generations of respective crosses. Observations were recorded on single plant basis for days to first flower, days to maturity, plant height, branches per plant, pods per plant, seeds per pod and seed yield per plant. Average value for each character was worked out and used for statistical analysis. To confirm presence or absence of epistasis, simple as well as joint scaling test (as described by Hayman and Mather, $1955^{[7]}$ and Cavalli, 1952) ${ }^{[2]}$ was carried out. Various gene effects were estimated using six parameter model as suggested by Hayman $(1958)^{[6]}$.

\section{Results and Discussion}

The mean values of all the six generations viz., $\mathrm{P}_{1}, \mathrm{P}_{2}, \mathrm{~F}_{1}, \mathrm{~F}_{2}$, $\mathrm{BC}_{1}$ and $\mathrm{BC}_{2}$ for eleven different characters were first subjected to genetic analysis. The test of adequacy of scale is important because in most of the cases the estimation of additive and dominance components of variances is made assuming the absence of gene interaction.

\section{Days to first flower}

Scaling test A, B and D were found significant which indicated the non-allelic gene action, and also significance of both simple scaling test as well as $\chi^{2}$ value of joint scaling test indicates inadequacy for additive dominance model. Dominance $(\mathrm{h})$, additive $\times$ additive (i) and dominance $\times$ dominance (l) interaction were found highly significant. The result of best fit model indicates the presence of significant additive (d), dominance (h) and two types of non-allelic interactions viz., additive $\times$ additive (i) and dominance $\times$ dominance (l). On the basis of sign of (h) and (l), duplicate type of gene action was found responsible for inheritance of this trait. The result indicated that additive (d), dominance (h) and epistatic component of genetic variance play major role in the inhetitance of this trait. Similar result was also found by Rehman et al. (2009), Bhagirath et al. (2013) ${ }^{[1]}$ and Gupta et al. $(2017)^{[4]}$.

\section{Days to maturity}

Among all four scales, only B scaling test was found significant and $\chi^{2}$ value of joint scaling test was also significant. Based on result of six parameter model, dominance $(\mathrm{h})$ and dominance $\times$ dominance (l) parameters were observed significant. Result of best fit model indicated highly significant value of additive (d) and dominance (h) component of genetic variance. The result showed that in the governance of this character additive (d), dominance (h) and dominance $\times$ dominance (l) type of epistatis had significance importance. These findings are in accordance with Durga Prasad and Murugan (2015) ${ }^{[3]}$, Kachave et al. (2015) ${ }^{[8]}$ and Gupta et al. (2017) ${ }^{[4]}$.

\section{Plant height (cm)}

For this chraracter scaling tests $\mathrm{A}$ and $\mathrm{C}$ were highly significant which indicated the presence of epistasis. As far as estimation of genetic component is concerned additive (d) components was observed highly significant, while only one interaction dominance $\times$ dominance (l) was found highly significant. According to reduced model by omitting nonsignificant parameter, all parameters viz., additive, dominance, additive $\times$ dominance and dominance $\times$ dominance were found highly significant except additive $x$ additive. Inheritance of this character was governed by duplicate type of gene action which, revealed that the character was influence by additive (d), dominance (h) as well as epistatic component. Similar results were also reported by Khattak et al. (2004) ${ }^{[11]}$, Khan et al. (2007) ${ }^{[10]}$, Tchiagam et al. (2011) ${ }^{[14]}$ and Kachave et al. (2015) ${ }^{[8]}$.

\section{Branches per plant}

Significance of C and D scaling test as well as highly significant $\chi^{2}$ value of joint scaling test revealed presence of non-allelic gene effect in the inheritance this trait. Additive (d), dominance (h) and additive $\times$ additive (i) gene effects found highly significant in six parameter model as well as in best fit model. The result showed that the character was governed by additive, dominance as well as additive $x$ additive type of epistasis. These findings are similar with the findings of Singh and Dikshit (2003) ${ }^{[13]}$, Haque et al. (2013) ${ }^{[5]}$ and Gupta et al. $(2017)^{[4]}$.

\section{Pods per plant}

Scaling tests A and D were found significant which indicated presence of non-allelic interaction. But, result of joint scaling test was more reliable than the scaling test; in this test $\chi^{2}$ value was observed non-significant, which indicate absence of nonallelic interaction and adequacy of three parameter model for the inheritance of trait under consideration.

\section{Seeds per pod}

Scaling test $\mathrm{C}$ and $\chi^{2}$ value of joint scaling test were found significant which revealed that character was influenced by non-allelic interactions. All the genetic parameters in six parameter model were found non-significant. However, result of best fit model indicated significant estimate of additive (d), additive $\times$ additive (i) and additive $\times$ dominance (j). The result indicated that additive and additive type of epistasis play major role in the governance of this trait. Similar results were also found by Haque et al. (2013) ${ }^{[5]}$, Kachave et al. (2015) ${ }^{[8]}$ and Gupta et al. $(2017)^{[4]}$.

\section{Seed yield per plant (g)}

Out of four, only one scaling test $\mathrm{C}$ was found significant and result of joint scaling test depicted significance of $\chi^{2}$ value. The result of six parameter model shows that dominance (h) components was significant and other genetic components registered non-significant value. The same components were also found significant in best fit model indicated that the character was govern by only dominant gene action. Similar results were also reported by Rehman et al. (2009) ${ }^{[12]}$, Bhagirath et al. (2013) ${ }^{[1]}$ and Kachave et al. (2015) ${ }^{[8]}$. 
Table 1: Estimates of scaling test and joint scaling test for various characters in blackgram of cross NUK-15-02 $\times$ NUK-15-09

\begin{tabular}{|c|c|c|c|c|c|c|c|c|}
\hline \multirow{2}{*}{ Character } & \multicolumn{3}{|c|}{ Simple scaling test } & \multicolumn{4}{|c|}{ Joint scaling test } & \multirow{2}{*}{$\chi^{2}$ value } \\
\hline & $\mathbf{A}$ & B & C & D & m & d & $\mathbf{h}$ & \\
\hline Days to first flower & $-4.73 * * \pm 1.23$ & $-2.73 * \pm 1.22$ & $-1.60 \pm 1.91$ & $2.93 * * \pm 0.89$ & $64.62 * * \pm 0.36$ & $0.90 * * \pm 0.34$ & $-5.91 * * \pm 0.69$ & $19.46^{* *}$ \\
\hline Days to $n$ & $-1.20 \pm 1.34$ & $-4.20 * * \pm 1.45$ & $-2.86 \pm 2.21$ & $1.26 \pm 0.97$ & $82.64 * * \pm 0.41$ & $-1.25 * * \pm 0.15$ & $-3.28 * * \pm 0.66$ & $8.40 *$ \\
\hline Plan & $-15.26 * * \pm 2.04$ & $-16.00 * * \pm 2.51$ & $-21.46 * * \pm 4.41$ & $4.90 * * \pm 1.82$ & $34.59 * * \pm 0.33$ & $-6.43 * * \pm 0.27$ & $-14.74 * * \pm 1.55$ & $67.79 * *$ \\
\hline Bran & $-0.93 \pm 0.72$ & & $-3.20 * * \pm 1.18$ & $-1.20 * \pm 0.50$ & $5.28 * * \pm 0.20$ & $-0.93 * * \pm 0.18$ & $1.43 * * \pm 0.41$ & $11.86^{* *}$ \\
\hline & $4.46 * \pm 2.14$ & $0.53 \pm 2.52$ & $-3.06 \pm 3.37$ & $-4.03 * \pm 1.90$ & $14.76 * * \pm 0.62$ & $0.76 \pm 0.64$ & $4.30 * * \pm 1.05$ & 8.24 \\
\hline Seeds per pod & $-0.66 \pm 0.44$ & $0.66 \pm 0.45$ & $1.20 * \pm 0.58$ & $0.60 \pm 0.34$ & $6.67 * * \pm 0.11$ & $0.47 * * \pm 0.12$ & $0.96 * * \pm 0.19$ & $10.52 *$ \\
\hline Seed yield per plant & $-0.35 \pm 0.75$ & $-0.90 \pm 0.86$ & $-2.65^{*} \pm 1.31$ & $-0.70 \pm 0.60$ & $5.01 * * \pm 0.20$ & $-0.77 * * \pm 0.20$ & $-0.45 \pm 0.97$ & $1.29 *$ \\
\hline
\end{tabular}

Table 2. Estimates of gene effects for various characters in blackgram for cross NUK-15-02 × NUK-15-093

\begin{tabular}{|c|c|c|c|c|c|c|}
\hline \multirow{2}{*}{ Character } & \multicolumn{5}{|c|}{ Six parameter model (Hyaman, 1958) } \\
\cline { 2 - 7 } & $\mathbf{m}$ & $\mathbf{d}$ & $\mathbf{h}$ & $\mathbf{i}$ & $\mathbf{j}$ & \multicolumn{1}{c|}{$\mathbf{l}$} \\
\hline Days to first flower & $62.08^{* *} \pm 0.31$ & $0.23 \pm 0.63$ & $-11.23^{* *} \pm 1.92$ & $-5.86^{* *} \pm 1.78$ & $-1.00 \pm 0.76$ & $13.33^{* *} \pm 3.18$ \\
\hline Days to maturity & $81.06^{* *} \pm 0.34$ & $-0.26 \pm 0.69$ & $-5.30^{*} \pm 2.13$ & $-2.53 \pm 1.94$ & $1.50 \pm 0.84$ & $7.93^{*} \pm 3.56$ \\
\hline Plant height (cm) & $27.51^{* *} \pm 0.74$ & $-5.73^{* *} \pm 1.04$ & $-16.36^{* *} \pm 3.99$ & $-9.80^{* *} \pm 3.64$ & $0.36 \pm 1.21$ & $41.06^{* *} \pm 6.08$ \\
\hline Branches per plant & $5.50^{* *} \pm 0.19$ & $-1.26^{* *} \pm 0.32$ & $4.20^{* *} \pm 1.10$ & $2.40^{*} \pm 1.00$ & $-0.53 \pm 0.40$ & $-1.60 \pm 1.76$ \\
\hline Pods per plant & - & - & - & - & - & - \\
\hline Seeds per pod & $7.36^{* * \pm 0.10}$ & $-0.06 \pm 0.27$ & $-0.26 \pm 0.72$ & $-1.20 \pm 0.69$ & $-0.66 \pm 0.30$ & $1.20 \pm 1.22$ \\
\hline Seed yield per plant & $5.10^{* *} \pm 0.21$ & $-0.49 \pm 0.42$ & $2.90^{*} \pm 1.30$ & $1.40 \pm 1.21$ & $0.27 \pm 0.48$ & $-0.14 \pm 2.15$ \\
\hline
\end{tabular}

Table 3: Best fit model for various characters in blackgram for cross NUK-15-02 × NUK-15-09

\begin{tabular}{|c|c|c|c|c|c|c|}
\hline \multirow{2}{*}{ Character } & \multicolumn{7}{|c|}{ Best fitting model model (Mather and jink) } \\
\cline { 2 - 7 } & $\mathbf{m}$ & $\mathbf{d}$ & $\mathbf{h}$ & $\mathbf{i}$ & $\mathbf{j}$ & $\mathbf{1}$ \\
\hline Days to first flower & $71.04^{* *} \pm 1.83$ & $0.93^{* *} \pm 0.34$ & $-24.59^{* *} \pm 4.77$ & $-5.88^{* *} \pm 1.78$ & - & $13.35^{* *} \pm 10.17$ \\
\hline Days to maturity & $82.64^{* *} \pm 0.41$ & $-1.25^{* *} \pm 0.39$ & $-3.28^{* *} \pm 0.81$ & - & - & - \\
\hline Plant height $(\mathrm{cm})$ & $45.71^{* *} \pm 3.59$ & $-6.00^{* *} \pm 0.53$ & $-56.67^{* *} \pm 8.62$ & $-9.58^{* *} \pm 3.55$ & - & $40.55^{* *} \pm 5.85$ \\
\hline Branches per plant & $3.80^{* *} \pm 0.53$ & $-0.97^{* *} \pm 0.18$ & $3.58^{* *} \pm 0.83$ & $1.73^{* *} \pm 0.58$ & - & - \\
\hline Pods per plant & - & - & - & - & - & - \\
\hline Seeds per pod & $7.39^{* *} \pm 0.07$ & $0.59^{* *} \pm 0.13$ & - & $-0.83^{* *} \pm 0.16$ & $-1.36^{*} \pm 0.60$ & - \\
\hline Seed yield per plant & $5.18^{* *} \pm 0.21$ & - & $2.90^{*} \pm 1.30$ & - & - & - \\
\hline
\end{tabular}

\section{Conclusion}

The significance of $\mathrm{C}$ scaling test for seed yield per plant and its components characters indicated the presence of appreciable amount of epistasis and inadequacy of additivedominance model. For seed yield per plant and most of the component characters both additive and dominance gene effects were found to be significant. In present study nonallelic interactions along with additive and dominant component played pertinent role in determination of various characters in blackgram. In general, involvement of both additive and non-additive gene effects for most of the characters suggested that it would be desirable to adopt biparental mating followed by population improvement method of breeding involving conventional breeding approach of selection of superior recombinants and their inter-mating for the development of elite homozygous recombinants having high quality and high yielding potentiality. Thus, population improvement approaches involving inter mating of selected plant in advance generation like biparental mating and diallel selective mating design that take care of both additive and non-additive gene actions are more promising for the improvement of various characters studied.

\section{References}

1. Bhagirath R, Tikka SBS, Acharya S. Heterosis and combining ability in blackgram (Vigna mungo (L.) hepper) under different environments. Indian J of Agric. Sci. 2013; 83(6):611-616.

2. Cavalli LL. An analysis of linkage of quantitative inheritance. In: Quantitative inheritance (Eds. E. C. R. Reeve and C. H. Wedelington). HMSO, London, 1952, 135-144.
3. Durga Prasad AVS, Murugan E. Combining ability analysis for yield and its attributes in Black gram (Vigna mungo (L.) Hepper). Elect. J Pl. Breed. 2015; 6(2):417423.

4. Gupta RP, Patel SR, Modha KG, Wadekar PB. Generation Mean Analysis for Yield and Yield Components in Cowpea [Vigna unguiculata (L.) Walp.] Int. J. Curr. Microbiol. App. Sci. 2017; 6(7):2231-2240.

5. Haque AFMM, Samad MA, Sarker N, Sarker JK, Azad AK, Deb AC et al. Gene effects of some agronomic traits through single cross analysis in blackgram (Vigna mungo L. Hepper). International J Biosci. 2013; 3(6):220-225.

6. Hayman BI. The separation of epistatic from additive and dominance variation in generation. Heredity. 1958; 12:371-390.

7. Hayman BI, Mather K. The description of genic interactions in continuous variation. Biometrics. 1955; 11(1):69-82.

8. Kachave GA, Parde NS, Zate DK, Harer PN. Analysis of combining ability in Blackgram (Vigna mungo L. Hepper) International Journal of Advanced Research. 2015; 3(3):1139-1146

9. Karande SP, Rewale AP, Nilakh SB. Combining ability analysis in black gram (Vinga mungo (L.) hepper) Bioinfolet. 2013; 10(2):685-688.

10. Khan MG, Ahmad W, Khattak GSS, Siraj UD, Ahmad H. Studies on detection on epistasis and estimates of gene effects for secondary yield characters in [Vigna radiata (L.) Wilczek].Sarhad J Agric. 2007; 23(4):1013-1017.

11. Khattak GSS, Asharaf M, Khan M. S. Assessment of genetic variation for yield and yield components in 
mungbean [Vigna radiata $(\mathrm{L}$.$) Wilczek] using generation$ mean analysis.Pak. J Bot. 2004; 36(3):583-588.

12. Rehman AU, Ali MA, Atta BM, Saleem M, Abbas A, Mallahi AR et al. Genetic studies of yield related traits in mungbean (Vigna radiata L. Wilczek). Australian J. Crop Sci. 2009; 3(6):352-360.

13. Singh BB, Dikshit HK. Combining ability studies for yield and architectural traits in mung bean (Vigna radiata (L.) Wilczek). Indian J Genet. 2003; 63(4):351-352.

14. Tchiagam JBN, Youmbi E, Njintang NYJM, Maina AN. Generation means analysis of seed sucrose content in cowpea [Vigna unguiculata (L.) Walp.]. Asian J Agric. Sci. 2011; 3(6):475-480. 